\title{
The miR-29 family in hematological malignancies
}

\author{
Barbora Fiserovaa , Lenka Kubiczkovaa,b, Lenka Sedlarikova ${ }^{\mathrm{a}, \mathrm{b}}$, Roman Hajek ${ }^{\mathrm{a}, \mathrm{b}}$, Sabina Sevcikova ${ }^{\mathrm{a}, \mathrm{b}}$
}

\begin{abstract}
Background. MicroRNAs are short non-coding regulators of gene expression. The human miR-29 family consists of three members: miR-29a, miR-29b and miR-29c. Members of this family were found to be aberrantly expressed in various types of tumors, including hematological malignancies. This family was described to have both oncogenic and tumor suppressor features influencing various pathological processes, such as tumor growth and apoptosis. This review summarizes current knowledge about the miR-29 family in selected hematological malignancies.
\end{abstract}

Conclusion. Recent research of miR-29 family in hematological malignancies has proven its oncogenic as well as tumor suppressive potential. Nevertheless, the level of current evidence is not sufficient, and data remain inconclusive.

Key words: microRNA, miR-29 family, hematological malignancy, circulating miRNA

Received: December 13, 2013; Accepted with revision: June 12, 2014; Available online: July 4, 2014 http://dx.doi.org/10.5507/bp.2014.037

${ }^{a}$ Babak Myeloma Group, Department of Pathological Physiology, Faculty of Medicine, Masaryk University, Brno, Czech Republic ${ }^{b}$ Department of Clinical Hematology, University Hospital Brno

Corresponding author:Sabina Sevcikova, sevcik@med.muni.cz

\section{INTRODUCTION}

MicroRNAs (miRNAs) are short, non-coding and highly conserved RNAs, approximately $22 \mathrm{bp}$ in size ${ }^{1}$. The genes for miRNAs represent $1-2 \%$ of all known eukaryotic genes $^{2}$. They regulate gene expression, both at transcriptional and translational levels. A single miRNA molecule can control expression of various genes and vice versa, one gene can be regulated by various miRNAs ${ }^{3}$. MiRNAs act in a wide range of physiological biological processes, such as cell proliferation, differentiation, apoptosis and hematopoiesis $^{4-6}$. As all of these processes, as well as miRNAs levels, are dysregulated in solid tumors and hematological malignancies, it was confirmed that there is an association between miRNAs and cancer ${ }^{7}$. Despite the fact that miRNAs were discovered in 1993 ( ref. $^{8}$ ), it was only in 2002 that miR-15a and miR-16-1 were identified as potential cancer genes in the pathogenesis of chronic lymphocytic leukemia (CLL) highlighting the direct link between miRNAs deregulation and hematological malignancy ${ }^{9}$.

Genes for miRNA are frequently located at fragile sites and genomic regions involved in cancers, such as minimal regions of loss of heterozygosity, minimal regions of amplification (minimal amplicons), or common breakpoint regions, explaining the contribution of miRNAs to cancerogenesis ${ }^{10}$. Such localization may lead to upregulation of miRNAs levels or their downregulation during pathological processes. Further, depending on the mRNA target which miRNAs bind and regulate, they can act either as oncogenes (also called oncomirs) or as tumor suppressors ${ }^{11}$. Due to overexpression of miRNA targeting tumor suppressor gene, anti-oncogenic mechanisms can be inhibited, whereas defects of miRNA repressing onco- gene can lead to gain of oncogenic features. Both these roles have been demonstrated in tumors ${ }^{12-14}$. In general, miRNAs can affect specific cell development (e.g. B cell) or alter expression of components in miRNA biogenesis in hematological malignancies.

Canonical model of the miRNAs biosynthetic pathway involves several steps as shown in Fig. 1. In the nucleus, RNA polymerase II transcribes miRNA genes into long primary precursors - pri-miRNAs. These are recognized and cleaved by microprocessor complex including ribonuclease Drosha and dsRNA-binding protein Pasha (or DGCR8) (ref. $\left.{ }^{15,16}\right)$. Secondary precursors are short, about 70 nucleotides stem-loop structures, known as pre-miRNAs that are further actively transported to cytoplasm by exportins, Ran-GTP dependent transporters. In the cytoplasm, pre-miRNAs are processed near the terminal loop by RNase III type endonuclease Dicer, which is in complex with dsRNA-binding protein TRBP (TAR RNA binding protein), and this generates mature miRNA/ miRNA* duplexes ${ }^{17,18}$. Subsequently, one strand of mature miRNA (so-called guide strand), which is less stable at the duplex 5'end, is incorporated into the Argonaut protein, a central part of multiprotein complex miRISC (miRNAinduced silencing complex). The other strand, called the passenger strand (miRNA*), is released from the duplex and degraded. The question of gene fate now lies in the RISC complex with incorporated mature miRNA because this is the site where gene mRNA and miRNA pair. If the complementarity between the seed sequence of miRNA (2-8 nucleotides at 5'end) and the 3'UTR of the target mRNA is perfect, mRNA is cleaved and degraded. In the other case, low degree of complementarity leads to inhibition of mRNA translation (Fig. 1) (ref. ${ }^{19}$ ). 


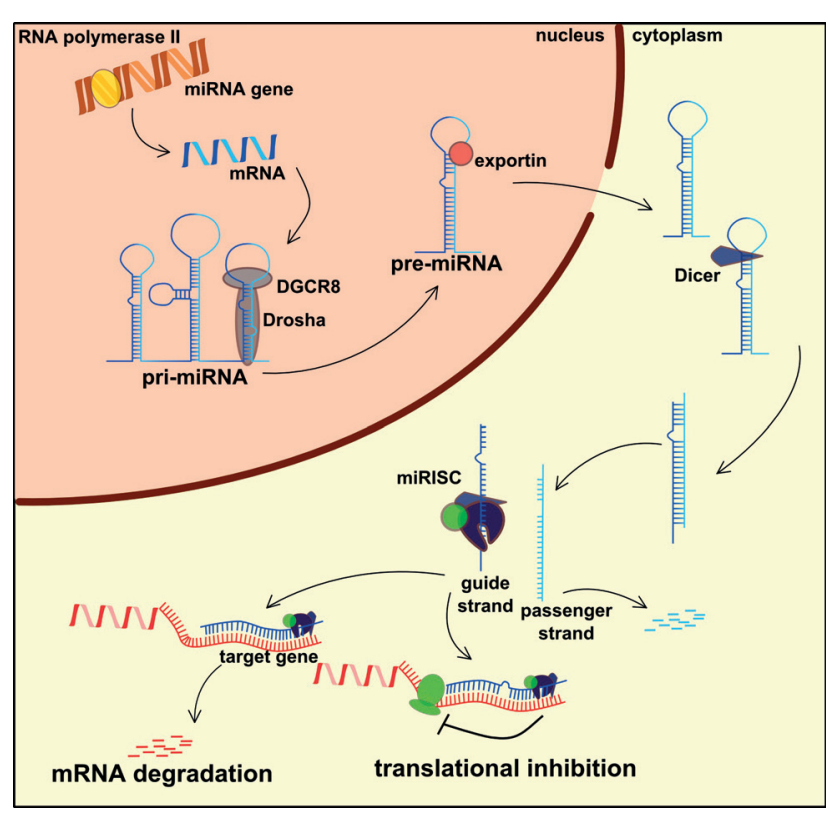

Fig. 1. MiRNA biogenesis. miRNA genes are transcribed in the nucleus, into long primary precursors - pri-miRNAs. Then, they are cleaved by Drosha and Pasha. Secondary precursors are short, stem-loop structures, known as pre-miRNAs that are further actively transported to cytoplasm by exportins. In the cytoplasm, pre-miRNAs are processed near the terminal loop by RNase III type endonuclease Dicer, and this generates mature miRNA/miRNA* duplexes.

\section{THE MIR-29 FAMILY}

In the human miR-29 family, the precursors are transcribed into two clusters, miR-29a/miR-29b-1 from chromosome region 7q32, and miR-29b-2/miR-29c from chromosome region 1q32. As the only difference between miR-29b-1 and miR-29b-2 is their localization in different parts of genome, they both form identical mature miR$29 \mathrm{~b}$. The first discovered member of the family was miR29a in HeLa cells in 2001 ( ref. $^{20}$ ), followed by miR-29b and miR-29c (ref. ${ }^{21,22}$ ).

The members of the miR-29 family have identical seed sequence, similar expression patterns as well as function. The only differences among miR-29 members were reported in their expression levels in various cancerous tissues as some studies claim that miR-29a or miR-29c do not follow the same expression pattern as miR-29b (ref. $\left.{ }^{23}\right)$. It was described that in lung cancer, only miR-29b-2 was differentially expressed ${ }^{24}$. Further, miR-29b was found to be differentially expressed in cholangiocytes and in brain malignancies ${ }^{25,26}$. Another study demonstrated that expression of miR-29a and miR-29c in cervical cancer was decreased $^{27}$. These results suggest that miR-29 is not tissue-specific.

\section{MIR-29 UNDER PHYSIOLOGICAL CONDITIONS}

The miR-29 family regulates several signaling pathways that are involved in various physiological and pathological processes. Physiologically, it takes part in regulation of cell cycle and proliferation ${ }^{27-30}$, senescence ${ }^{31,32}$, differentia$\operatorname{tion}^{33,34}$, apoptosis ${ }^{25,28,30,35,36}$, metastasis ${ }^{37,38}$, DNA methylation $^{39-41}$ and immune regulation ${ }^{42,43}$, as well as regulation of extracellular matrix (ECM).

\section{MiR-29 in cell cycle, proliferation and differentiation}

Progression through the eukaryotic cell cycle is driven by cyclin-dependent kinases (CDKs), which are regulated by interaction with oscillatory expressed proteins called cyclins $^{44}$. In cell cycle progression, from G1 to S phase, cyclin D1 binds CDK6 and CDK4 which then phosphorylate and inactivate $\mathrm{Rb}$ protein. These $\mathrm{CDK}$ s are essential for response to mitogenic stimuli, therefore the loss of CDK6 affects production of terminally differentiated cells (Fig. 2) $\left(\right.$ ref. $^{45}$ ). It was demonstrated that 3'UTR of CDK6 contains 2 conserved sequence motifs with perfect homology to miR-29 seed sequence; therefore, CDK6 was suggested as a direct target of miR-29 ( ref. $^{29}$ ).

In terms of its role in cell differentiation, miR-29b has multiple functions in osteoblastogenesis - to control collagen expression during ECM maturation is one of them. However, this process does not happen in immature cells. Instead, miR-29b helps to maintain the differentiated phenotype in osteoblasts through regulating collagen. On the other hand, miR-29b downregulates negative regulators of signaling pathways to promote osteoblastogenesis. Both these miR-29b roles regulate osteoblast differentiation ${ }^{46}$. In another study, miR-29a and miR-29c were shown to be induced by the Wnt pathway that is critical in osteoblast differentiation. During the late phases of osteoblast differentiation, the expression of these miRNAs is upregulated and increased. Beside this, miR-29a and miR-29c downregulate osteoblast differentiation by targeting osteonectin, an essential protein for bone remodeling ${ }^{33}$.

Apart from osteoblast differentiation, miR-29 was reported to play a role in muscle cells development. The miR-29 family enhances myogenic differentiation through its involvement in the NF-kB-YY1 regulatory loop. In myogenesis, downregulated transcription factors NF- $\mathrm{B}$ and Yin Yang 1 (YY1) decrease miR-29 levels and this in turn induces differentiation by targeting YY1 (ref. ${ }^{34}$ ).

Another experiment showed that miR-29 together with miR-142 also regulates monocytic and granulocytic

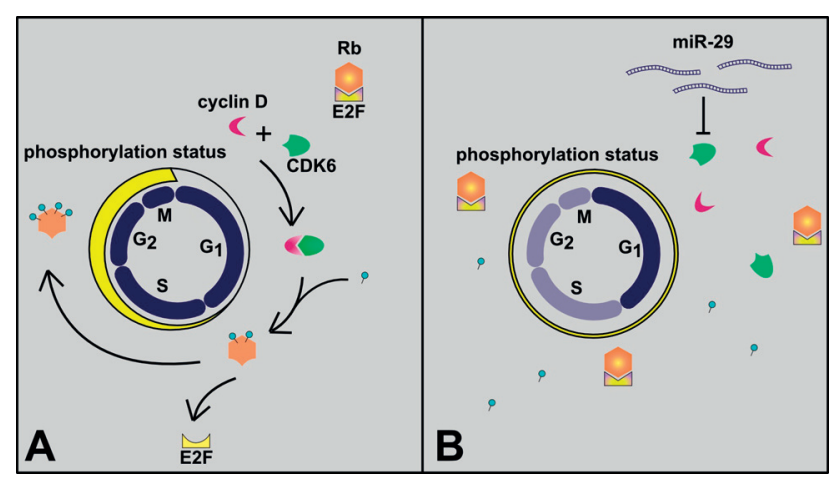

Fig. 2. MiR-29 function in cell cycle. (A) Cell cycle without miR-29 influence, (B) MiR-29 inhibits Cdk6 which cannot bind with cyclin $\mathrm{D}$ and phosphorylate $\mathrm{Rb}$; therefore, cell is not differentiated. 
(myeloid) differentiation. Targeting CDK6 by miR-29, as well as targeting cyclin T2 (CCNT2), a component of positive transcription elongation factor $\mathrm{b}$ (P-TEFb), by either miR-29 or miR-142 increases myeloid differentiation ${ }^{47}$.

\section{Aging processes and senescence}

MiR-29 might be a pro-aging miRNA as it accumulates during aging and its upregulation is associated with DNA damage response. MiR-29 is part of the signaling pathway involving Ppm1d/Wip1 phosphatase, a key DNA damage response regulator, and the p53 tumor suppressor (Fig. 3) (ref. ${ }^{31}$ ). Further effects of miR-29 during cellular senescence were described in association with B-Myb which is an oncogene and a transcription factor for various genes involved in proliferation ${ }^{48}$. Besides these functions, B-Myb is able to induce senescence by inhibition of its transcrip$\operatorname{tion}^{49}$. One of the options for repressing abundant B-Myb mRNA is through binding of Rb-E2F complexes to B-Myb promoter ${ }^{50}$. The other option of B-Myb repression at the posttranscriptional level involves miRNAs. MiR-29 together with miR-30 directly targets B-Myb 3'UTR and reduce its expression in cells undergoing senescence ${ }^{32}$. These facts are also consistent with miR-29 suppressor function in cancer.

\section{ECM regulation}

ECM regulation includes formation of extracellular matrix key proteins, e.g. various collagen (COL) isoforms, elastins, metalloproteinases, etc (ref..$\left.^{23,46}\right)$. In osteoblasts, miR-29 regulates essential proteins of bone ECM. It mediates translational inhibition and decreases COL1A1, COL5A3, COL4A2 synthesis; furthermore, it maintains differentiated phenotype in mature cells ${ }^{46}$. The broad spectrum of collagens and other related genes, e.g. matrix metallopeptidase 2, which are miR-29 targets, was confirmed and even extended in a study done on rats. There were 20 genes for collagen predicted as miR-29 targets which makes this miRNA unique because no other miRNA targeted more than 11 collagen genes ${ }^{23}$.

Regulation of these proteins by miR-29 is implicated in the development of fibrosis in many organs ${ }^{51-53}$ and

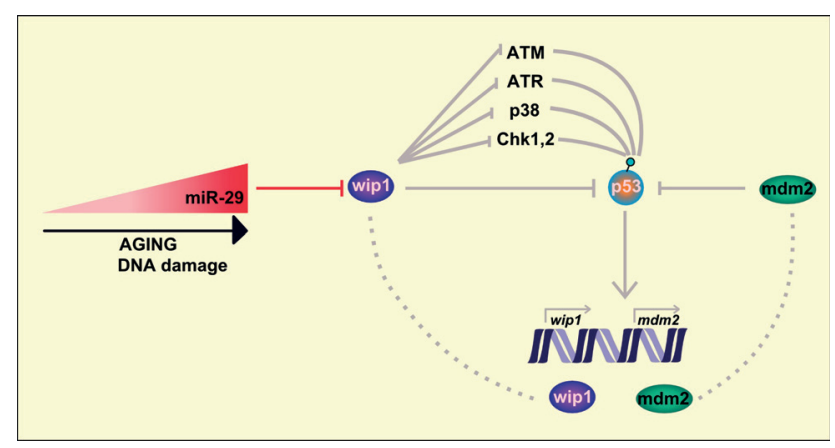

Fig. 3. Inhibition of p53 pathway by miR-29. Upregulation of miR-29 with increasing age and DNA damage inhibits Wip1 phosphatase. After that, Wip1 phosphatase cannot repress DNA damage responsefactors and $\mathrm{p} 53$. Wip 1 and $\mathrm{mdm} 2$ are not transcribed by p53 which is not phosphorylated. Cell cycle is arrested. systemic sclerosis ${ }^{54}$. Not only in mice developing liver fibrosis, but also in patients with hepatic fibrosis, the miR29 family was significantly downregulated and inhibited collagen expression in hepatic stellate cells ${ }^{52}$. A significant decrease was also found in the lungs of idiopathic pulmonary fibrosis patients ${ }^{53}$.

\section{MIR-29 IN HEMATOLOGICAL MALIGNANCIES}

Despite the range of physiological processes the miR29 family is involved in, most studies concentrate on its pathological function and tumor suppressive or oncomir (oncogenic miRNA) effects in various cancers. In terms of solid tumors and hematological malignancies, both these roles have been proven; they are believed to depend on cellular context or tissue specificity. Although expression of miR-29 was found to be altered in cancer, its role in pathogenesis of hematological malignancies is still poorly understood ${ }^{55}$. There is, however, a predominance of publications supporting the tumor suppressor role of the miR-29 family. By targeting oncogenes, the miR-29 family helps prevent carcinogenesis; therefore, in cancer, its levels are downregulated (Table 1) (ref. ${ }^{12,56,57}$ ).

Furthermore, it was observed that miR-29 is associated with some cytogenetic aberrations. MiR-29, among other miRNAs, was found to be down-regulated in acute myeloid leukemia (AML) patients with 11q23 balanced translocation compared to AML patients without this translocation $^{56}$. Further, Garzon et al. observed that miR29a and miR-29b are downregulated in primary AML samples with monosomy of chromosome 7. However, forced expression of these miRNAs had first anti-proliferative effects and later anti-apoptotic effects in AML cell lines and primary AML blasts, thus inhibiting cell growth and induced apoptosis by targeting Mcl-1 (Myeloid cell leukemia-1) (ref. ${ }^{28}$ ). In AML patients with monosomy of chromosome 7 or deletion of 7q, a link between miR-29a and oncogene Ski was described as the nuclear oncogene Ski is upregulated and miR-29a located on 7q32 is downregulated in these AML patients. Further, it was shown that miR-29a targets Ski, as their expression is inversely correlated, which suggest the tumor suppressive role of miR-29a (ref. ${ }^{58}$ ). Although previous study reported also tumor suppressor miR-29 family to be upregulated in AML patients with mutations in the nucleophosmin (NPM) gene when compared to wild type NPM (ref. ${ }^{59}$ ); however, this was not confirmed and miR-29 downregulation was described in AML patients independently of the NPM status $^{60}$.

A genome-wide profiling study on CLL (chronic lymphocytic leukemia) revealed that miR-29 precursors are upregulated $^{61}$. Afterwards, another study demonstrated downregulated miR-29a in aggressive CLL compared to indolent CLL (ref. ${ }^{35}$ ). Interestingly, miR-29a was found to be the second and miR-29c the fifth most represented miRNA among the most expressed miRNAs in CLL (ref. $\left.{ }^{62}\right)$. 
Despite some knowledge about miR-29 in other hematological malignancies, little is known about this miRNA in mantle cell lymphoma (MCL) and further research in this field is needed. One report showed notably decreased miR-29 levels in MCL patients, which were associated with higher levels of its target CDK6 and with shorter overall survival of MCL patients. Therefore, the use of miR-29 as a prognostic marker and pathogenetic factor in MCL was suggested ${ }^{29}$.

Besides studying direct miR-29 family effects and its participation in regulation, there is an effort to apply miR29 as novel biomarkers. The analysis of miR-29a together with miR-142-3p indicated that these miRNAs could be used as AML molecular diagnostic markers. Because of their key role in regulation of normal myeloid differentiation, miR-29a and miR-142-3p abnormal expression was shown to be involved in AML development, as it directly affected target genes important in AML (ref. ${ }^{60}$ ). Recently, the first evidence of miR-29a as an unfavorable prognostic marker in AML was indicated, as downregulation of miR29a was shown to be associated with advanced clinical features and poor prognosis in pediatric AML patients ${ }^{63}$.

\section{Apoptosis in hematological malignancies}

Majority of studies show that miR-29 family effects in cancer are anti-apoptotic. However, in studied hematological malignancies, the miR-29 levels were lower than in physiological conditions. Therefore the tumor suppressive impact of miR-29 on cancer cells is poor (Table 1). MiR-29 family was described to target genes involved in regulation of apoptosis, such as Bcl-2 (B-cell leukemia/ lymphoma) family members and a key anti-apoptotic protein Mcl-1 that are often dysregulated in malignant cells (Table 2). Constitutive Mcl-1 expression can cause malignant transformation as was demonstrated in transgenic mice $^{64}$. MiR-29b negatively regulates Mcl-1 protein expression; low miR-29b levels upregulate Mcl-1 expression and thus induce anti-apoptotic signals and may play a role in tumor development. On the other hand, experiments with enforced miR-29b expression showed sensitivity to cell death which might be valuable in cancer therapy ${ }^{25}$.
In multiple myeloma (MM), a plasma cell malignancy, the miR-29b tumor suppressor effects are implicated as well. It was shown that miR-29b is downregulated in MM; however, its overexpression can downregulate Mcl-1 expression and is associated with caspase-3 activation. By targeting critical oncogenic pathways, miR-29b inhibits growth and induces apoptosis of MM cells ${ }^{12}$.

Another miR-29 family target is Tcll (T-cell leukemia/ lymphoma 1) gene), a significant oncogene involved in CLL pathogenesis. Tcl1 operates as a coactivator of the Akt oncoprotein that is important in the anti-apoptotic pathway in B- and T-cells ${ }^{65,66}$. Pekarsky et al. demonstrated that miR-29 family members are partly natural Tcl1 inhibitors and that downregulated miR-29 levels in aggressive CLL might be a causal event in disease pathogenesis ${ }^{35}$. Another study suggested that the downregulation of miR29 upregulates Tcl1 in aggressive CLL, and thus develops aggressive phenotype ${ }^{14}$.

Amodio et al. recently identified new miR-29b target $\mathrm{Sp} 1$, a transcription factor that participates in cell cycle regulation and apoptosis ${ }^{67}$. In MM, Sp1 is involved in cell survival and promotes MM cell growth ${ }^{68}$. Sp1 is downregulated by miR-29 but it was demonstrated that the forced expression of miR-29b in cell lines inhibited cell growth and triggered apoptosis in vitro and in vivo in a murine model. Besides this, miR-29b-Sp1 regulatory loop was described. Not only miR-29b influences Sp1 but also $\mathrm{Sp} 1$ negatively regulates miR-29b. Upregulated Sp1 transcriptionally inhibits miR-29b and silenced Sp 1 increases miR-29b levels. All of this may prevent the tumor formation in a model of MM ( ref. $^{67}$ ).

A study done by Garzon et al. describes the effects of miR-29 on both apoptosis and proliferation in AML cells. The forced expression of miR-29a and miR-29b led to cell growth inhibition and induction of apoptosis. After the transfection of the miRNAs, the first observed effect was inhibition of apoptosis. It was confirmed that Mcl1 and other anti-apoptotic genes are miR-29 targets and that this miRNA also upregulates proapoptotic genes. The anti-proliferative effect was observed later after the transfection, which means that the miR-29-dependent pro-

Table 1. MiR-29 involvement in cancer.

\begin{tabular}{llll}
\hline Target & MiR-29 function & MiR-29 regulation & Cancer development \\
\hline Oncogene & Tumor suppressor & upregulated & no \\
& & downregulated & induced \\
Tumor suppressor & Oncomir & upregulated & induced \\
& & downregulated & no \\
\hline
\end{tabular}

Table 2. Oncogenes as miR-29 targets in hematological malignancies.

\begin{tabular}{llll}
\hline Target & Function & miR-29 member & References \\
\hline Mcl-1 & Cell survival, proliferation, apoptosis & miR-29b & $12,25,64$ \\
Tcl-1 & Apoptosis & not specified & 35 \\
Sp1 & Cell growth, survival & miR-29b & 67 \\
SKI & Nuclear corepressor complexes & miR-29a & 58 \\
CDK6 & Cell cycle & not specified & 29 \\
\hline
\end{tabular}


liferation is not a result of apoptosis. For studying miR-29 impact on proliferation, CDK6, a miR-29 target, was chosen. Transfection of miR-29b into AML cells indirectly led to decreased $\mathrm{Rb}$ phosphorylation through CDK6, which resulted in decreased proliferation ${ }^{28}$.

\section{Tumor initiation and growth}

Although tumor suppressor effect of miR-29a was elucidated, some studies show that the miR-29 family has also tumor promoting effects, but this oncomir function still remains poorly understood. The first example of a miRNA initiating AML in vivo was reported by Han et al. They showed that miR-29a was highly expressed in human AML and its overexpression led to higher incidence of AML. MiR-29a can induce AML by converting myeloid progenitors into self-renewing leukemia stem cells, thus showing oncogenic potential ${ }^{13}$. The same was demonstrated in CLL where miR-29a was overexpressed in indolent CLL in comparison to normal B cells. However, a hypothesis of solely miR-29 initiating leukemia was not confirmed $^{14}$.

As for MM, one of its main characteristics is bone disease which is a result of imbalance between osteoblasts and osteoclasts bone formation caused by MM cells. It was found that miR-29b expression decreases during osteoclast differentiation in vitro and suppresses its targets c-Fos and metalloproteinase 2. miR-29b-based treatment of MM-related disease was suggested when the results showed enforced miR-29b expression disrupting osteoclast differentiation and overcoming osteoclast activation ${ }^{69}$.

\section{CIRCULATING MIR-29}

In 2008, the discovery of miRNA present in body fluids was reported. MiRNAs were found in almost all body fluids, e.g. serum, plasma, saliva, urine, etc ( ref. $^{70-73}$ ). Interestingly, under unfavorable conditions, such as boiling, storage at room temperature, low or high $\mathrm{pH}$ or repeated cycles of freeze-thawing, plasma miRNAs were found to be unconventionally stable. Possibly, there are two mechanisms by which circulating miRNAs are protected from degradation. The first possibility is to form ribonucloeprotein complexes of miRNA and RNA-binding protein, e.g. Ago2 (ref. ${ }^{74}$ ), NPM-1 (ref. ${ }^{75}$ ) or high-density lipoproteins (HDLs) $\left(\right.$ ref. $\left.^{76}\right)$. The other option is packaging in small vesicles. Depending on the size and form of release, these small vesicles can be exosomes, which are released from endosome membrane, or microvesicles, that are shed directly from plasma membrane, or even apoptotic bodies ${ }^{77-80}$. Current evidence shows that the majority of circulating miRNAs are bound to proteins rather than found in vesicles. This aside, it seems that cells can actively select which miRNAs will be released from cells and which will stay within the cell ${ }^{81}$. However, little is known about circulating miRNA origins and factors in their regulation and other underlying mechanisms need to be determined.

Our own data showed the presence of circulating serum miR-29a in MM patients. Serum levels of miR- 29a were able to distinguish MM patients from healthy donors. Although further analysis is required, it is possible that circulating miRNAs represent a novel and easily accessible putative marker ${ }^{82}$. Such a marker would be important and highly clinically relevant in diseases such as MM, where frequent testing of bone marrow is not ethically permissible.

The question of comparing established biomarkers and circulating miRNAs was investigated in patients with CLL (ref. ${ }^{83}$ ). A set of 3 miRNAs, including miR29a, was able to distinguish healthy controls from CLL patients. Furthermore, another set of miRNAs, including miR-29a, was compared with $\mathrm{IgV}_{\mathrm{H}}$ and zeta-associated protein (ZAP) status, an established clinical risk stratifier in CLL (ref. ${ }^{84}$ ). This miRNA set could separate ZAP-70+ and ZAP-70' samples but did not correlate with $\mathrm{IgV}_{\mathrm{H}}$ mutation status ${ }^{83}$.

\section{CONCLUSION}

First dismissed as a type of junk RNA, miRNAs were demonstrated to be pivotal in gene regulation. In recent years, miRNAs have also been discovered to be important players in cancer pathogenesis and understanding of their significance has broadened. MiRNAs function both as tumor suppressors and oncomirs.

MiR-29 is involved in various physiological processes, such as proliferation, differentiation, apoptosis and senescence. It has also been shown that the miR-29 family is deregulated in hematological malignancies as well as in solid tumors. The analyses are influenced by heterogeneity of the diseases, detection methods used, various genetic background of patients/control groups, and different disease stage. In some cases, small data sets may impair data validation. However, its specific role in hematological malignancies remains unclear.

\section{ACKNOWLEDGEMENT}

The work was supported by the grant of The Ministry of Education, Youth and Sports MSM0021622434, by grant of the Ministry of Health NT12130 and NT14575, and grant MUNI/11/InGA17/2012.

The authors would like to thank John B. Smith for proofreading the manuscript.

Author contributions: BF: literature search and manuscript writing; LK, LS, RH: manuscript writing; SS: final approval.

Conflict of interest statement: None declared.

\section{REFERENCES}

1. Bartel DP. MicroRNAs: genomics, biogenesis, mechanism, and function. Cell 2004;116:281-97.

2. Lewis BP, Shih I, Jones-Rhoades MW, Bartel DP, Burge CB. Prediction of mammalian microRNA targets. Cell 2003;115(7):787-98.

3. Lindow M, Gorodkin J. Principles and limitations of computational microRNA gene and target finding. DNA Cell Biol 2007;26(5):339-51. 
4. Ambros V. MicroRNA pathways in flies and worms: growth, death, fat, stress, and timing. Cell 2003;113(6):673-6.

5. Monticelli S, Ansel KM, Xiao C, Socci ND, Krichevsky AM, Thai T-H, Rajewsky N, Marks DS, Sander C, Rajewsky K, Rao A, Kosik KS MicroRNA profiling of the murine hematopoietic system. Genome Biol [serial on the Internet]. 2005 Jan [cited 2013 Aug 6]; 6(8):[about 15 p.]. Available from: http://genomebiology.com/content/6/8/R71.

6. Chen C-Z, Lodish HF. MicroRNAs as regulators of mammalian hematopoiesis. Semin Immunol 2005;17(2):155-65.

7. Lu J, Getz G, Miska EA, Alvarez-Saavedra E, Lamb J, Peck D, SweetCordero A, Ebert BL, Mak RH, Ferrando AA, Downing JR, Jacks T, Horvitz HR, Golub TR. MicroRNA expression profiles classify human cancers. Nature 2005;435(7043):834-8.

8. Lee RC, Feinbaum RL, Ambros V. The C. elegans heterochronic gene lin-4 encodes small RNAs with antisense complementarity to lin-14. Cell 1993;75(5):843-54.

9. Calin GA, Dumitru CD, Shimizu M, Bichi R, Zupo S, Noch E, Aldler H, Rattan S, Keating M, Rai K, Rassenti L, Kipps T, Negrini M, Bullrich F, Croce $\mathrm{CM}$. Frequent deletions and down-regulation of micro-RNA genes miR15 and miR16 at 13q14 in chronic lymphocytic leukemia. Proc Natl Acad Sci U S A 2002;99(24):15524-9.

10. Calin GA, Sevignani C, Dumitru CD, Hyslop T, Noch E, Yendamuri $S$, Shimizu M, Rattan S, Bullrich F, Negrini M, Croce CM. Human microRNA genes are frequently located at fragile sites and genomic regions involved in cancers. Proc Natl Acad Sci U S A 2004;101(9):2999-3004.

11. Volinia S, Calin GA, Liu C-G, Ambs S, Cimmino A, Petrocca F, Visone R, Iorio M, Roldo C, Ferracin M, Prueitt RL, Yanaihara N, Lanza G, Scarpa A, Vecchione A, Negrini M, Harris CC, Croce CM. A microRNA expression signature of human solid tumors defines cancer gene targets. Proc Natl Acad Sci U S A 2006;103(7):2257-61.

12. Zhang Y-K, Wang H, Leng Y, Li Z-L, Yang Y-F, Xiao F-J, Li Q-F, Chen X-Q, Wang L-S. Overexpression of microRNA-29b induces apoptosis of multiple myeloma cells through down regulating Mcl-1. Biochem Biophys Res Commun 2011;414(1):233-9.

13. Han Y-C, Park CY, Bhagat G, Zhang J, Wang Y, Fan J-B, Liu M, Zou Y, Weissman IL, Gu H. microRNA-29a induces aberrant self-renewal capacity in hematopoietic progenitors, biased myeloid development, and acute myeloid leukemia. J Exp Med 2010;207(3):475-89.

14. Santanam U, Zanesi N, Efanov A, Costinean S, Palamarchuk A, Hagan JP, Volinia S, Alder H, Rassenti L, Kipps T, Croce CM, Pekarsky Y. Chronic lymphocytic leukemia modeled in mouse by targeted miR-29 expression. Proc Natl Acad Sci U S A 2010;107(27):12210-5.

15. Kim VN. MicroRNA biogenesis: coordinated cropping and dicing. Nat Rev Mol Cell Biol 2005;6(5):376-85.

16. Borchert GM, Lanier W, Davidson BL. RNA polymerase III transcribes human microRNAs. Nat Struct Mol Biol 2006;13(12):1097-101.

17. Kim VN. MicroRNA precursors in motion: exportin-5 mediates their nuclear export. Trends Cell Biol 2004;14(4):156-9.

18. Carthew RW, Sontheimer EJ. Origins and mechanisms of miRNAs and siRNAs. Cell 2009;136(4):642-55.

19. Ronemus M, Vaughn MW, Martienssen RA. MicroRNA-targeted and small interfering RNA-mediated mRNA degradation is regulated by Argonaute, Dicer, and RNA-dependent RNA polymerase in Arabidopsis. Plant Cell 2006;18(7):1559-74.

20. Lagos-Quintana M, Rauhut $R$, Lendeckel W, Tuschl T. Identification of novel genes coding for small expressed RNAs. Science (80- ) 2001;294(5543):853-8.

21. Lagos-Quintana M, Rauhut R, Yalcin A, Meyer J, Lendeckel W, Tusch T. Identification of tissue-specific microRNAs from mouse. Curr Biol 2002;12(9):735-9.

22. Dostie J, Mourelatos Z, Yang M, Sharma A, Dreyfuss G. Numerous microRNPs in neuronal cells containing novel microRNAs. RNA 2003;9(2):180-6.

23. Liu Y, Taylor NE, Lu L, Usa K, Cowley AW, Ferreri NR, Yeo NC, Liang M. Renal medullary microRNAs in Dahl salt-sensitive rats: miR$29 \mathrm{~b}$ regulates several collagens and related genes. Hypertension 2010;55(4):974-82.

24. Yanaihara N, Caplen N, Bowman E, Seike M, Kumamoto K, Yi M, Stephens RM, Okamoto A, Yokota J, Tanaka T, Calin GA, Liu C-G, Croce CM, Harris CC. Unique microRNA molecular profiles in lung cancer diagnosis and prognosis. Cancer Cell 2006;9(3):189-98.

25. Mott JL, Kobayashi S, Bronk SF, Gores GJ. mir-29 regulates Mcl-1 protein expression and apoptosis. Oncogene 2007;26(42):6133-40.

26. Silber J, Lim DA, Petritsch C, Persson Al, Maunakea AK, Yu M, Vandenberg SR, Ginzinger DG, James CD, Costello JF, Bergers G,
Weiss WA, Alvarez-Buylla A, Hodgson JG. miR-124 and miR-137 inhibit proliferation of glioblastoma multiforme cells and induce differentiation of brain tumor stem cells. BMC Med [serial on the Internet]. 2008 Jan [cited 2013 Aug 13]; 6:[about 17 p.]. Available from: http://www.biomedcentral.com/1741-7015/6/14.

27. Li Y, Wang F, Xu J, Ye F, Shen Y, Zhou J, Lu W, Wan X, Ma D, Xie X. Progressive miRNA expression profiles in cervical carcinogenesis and identification of HPV-related target genes for miR-29. J Patol 2011;224(4):484-95.

28. Garzon R, Heaphy CE, Havelange V, Fabbri M, Volinia S, Tsao T, Zanesi N, Kornblau SM, Marcucci G, Calin GA, Andreeff M, Croce CM. MicroRNA 29b functions in acute myeloid leukemia. Blood 2009;114(26):5331-41.

29. Zhao J-J, Lin J, Lwin T, Yang H, Guo J, Kong W, Dessureault S, Moscinski LC, Rezania D, Dalton WS, Sotomayor E, Tao J, Cheng JQ. microRNA expression profile and identification of miR-29 as a prognostic marker and pathogenetic factor by targeting CDK6 in mantle cell lymphoma. Blood 2010;115(13):2630-9.

30. Garzon R, Liu S, Fabbri M, Liu Z, Heaphy CE, Callegari E, Schwind S, Pang J, Yu J, Muthusamy N, Havelange V, Volinia S, Blum W, Rush LJ, Perrotti D, Andreeff M, Bloomfield CD, Byrd JC, Chan K, Wu L-C, Croce CM, Marcucci G. MicroRNA-29b induces global DNA hypomethylation and tumor suppressor gene reexpression in acute myeloid leukemia by targeting directly DNMT3A and $3 \mathrm{~B}$ and indirectly DNMT1. Blood 2009;113(25):6411-8.

31. Ugalde AP, Ramsay AJ, de la Rosa J, Varela I, Mariño G, Cadiñanos J, Lu J, Freije JM, López-Otín C. Aging and chronic DNA damage response activate a regulatory pathway involving miR-29 and p53. EMBO J 2011;30(11):2219-32.

32. Martinez I, Cazalla D, Almstead LL, Steitz JA, DiMaio D. miR-29 and miR-30 regulate B-Myb expression during cellular senescence. Proc Natl Acad Sci U S A 2011;108(2):522-7.

33. Kapinas K, Kessler CB, Delany AM. miR-29 suppression of osteonectin in osteoblasts: regulation during differentiation and by canonical Wnt signaling. J Cell Biochem 2009;108(1):216-24.

34. Wang H, Garzon R, Sun H, Ladner KJ, Singh R, Dahlman J, Cheng A, Hall BM, Qualman SJ, Chandler DS, Croce CM, Guttridge DC. NFkappaB-YY1-miR-29 regulatory circuitry in skeletal myogenesis and rhabdomyosarcoma. Cancer Cell 2008;14(5):369-81.

35. Pekarsky Y, Santanam U, Cimmino A, Palamarchuk A, Efanov A, Maximov V, Volinia S, Alder H, Liu C-G, Rassenti L, Calin GA, Hagan JP, Kipps T, Croce CM. Tcl1 expression in chronic lymphocytic leukemia is regulated by miR-29 and miR-181. Cancer Res 2006;66(24):115903.

36. Xiong Y, Fang J-H, Yun J-P, Yang J, Zhang Y, Jia W-H, Zhuang S-M. Effects of microRNA-29 on apoptosis, tumorigenicity, and prognosis of hepatocellular carcinoma. Hepatology 2010;51(3):836-45.

37. Gebeshuber CA, Zatloukal K, Martinez J. miR-29a suppresses tristetraprolin, which is a regulator of epithelial polarity and metastasis. EMBO Rep 2009;10(4):400-5.

38. Castilla MÁ, Moreno-Bueno G, Romero-Pérez L, Van De Vijver K, Biscuola M, López-García MÁ, Prat J, Matías-Guiu X, Cano A, Oliva $E$, Palacios J. Micro-RNA signature of the epithelial-mesenchymal transition in endometrial carcinosarcoma. J Pathol 2011;223(1):7280.

39. Fabbri M, Garzon R, Cimmino A, Liu Z, Zanesi N, Callegari E, Liu S, Alder H, Costinean S, Fernandez-Cymering C, Volinia S, Guler G, Morrison CD, Chan KK, Marcucci G, Calin GA, Huebner K, Croce CM. MicroRNA-29 family reverts aberrant methylation in lung cancer by targeting DNA methyltransferases $3 \mathrm{~A}$ and 3B. Proc Natl Acad Sci U S A 2007;104(40):15805-10.

40. Braconi C, Kogure T, Valeri N, Huang N, Nuovo G, Costinean S, Negrini M, Miotto E, Croce CM, Patel T. microRNA-29 can regulate expression of the long non-coding RNA gene MEG3 in hepatocellular cancer. Oncogene 2011;30(47):4750-6.

41. Morita S, Horii T, Kimura M, Ochiya T, Tajima S, Hatada I. miR-29 represses the activities of DNA methyltransferases and DNA demethylases. Int J Mol Sci 2013;14(7):14647-58.

42. Xu H, Cheung IY, Guo H-F, Cheung N-K V. MicroRNA miR-29 modulates expression of immunoinhibitory molecule B7-H3: potential implications for immune based therapy of human solid tumors. Cancer Res 2009;69(15):6275-81.

43. Steiner DF, Thomas MF, Hu JK, Yang Z, Babiarz JE, Allen CDC, Matloubian M, Blelloch R, Ansel KM. MicroRNA-29 regulates T-box 
transcription factors and interferon- $\gamma$ production in helper T cells. Immunity 2011;35(2):169-81.

44. Nigg EA. Cyclin-dependent protein kinases: key regulators of the eukaryotic cell cycle. Bioessays 1995;17(6):471-80.

45. Malumbres M, Sotillo R, Santamaría D, Galán J, Cerezo A, Ortega S, Dubus $P$, Barbacid M. Mammalian cells cycle without the D-type cyclin-dependent kinases Cdk4 and Cdk6. Cell 2004;118(4):493-504.

46. Li Z, Hassan MQ, Jafferji M, Aqeilan Rl, Garzon R, Croce CM, van Wijnen AJ, Stein JL, Stein GS, Lian JB. Biological functions of miR$29 \mathrm{~b}$ contribute to positive regulation of osteoblast differentiation. J Biol Chem 2009;284(23):15676-84.

47. Wang X-S, Gong J-N, Yu J, Wang F, Zhang X-H, Yin X-L, Tan Z-Q, Luo Z-M, Yang G-H, Shen C, Zhang J-W. MicroRNA-29a and microRNA$142-3 p$ are regulators of myeloid differentiation and acute myeloid leukemia. Blood 2012;119(21):4992-5004.

48. Joaquin M, Watson RJ. Cell cycle regulation by the B-Myb transcription factor. Cell Mol Life Sci 2003;60(11):2389-401.

49. Johung K, Goodwin EC, DiMaio D. Human papillomavirus E7 repression in cervical carcinoma cells initiates a transcriptional cascade driven by the retinoblastoma family, resulting in senescence. J Virol 2007;81(5):2102-16.

50. Zwicker J, Liu N, Engeland K, Lucibello FC, Müller R. Cell cycle regulation of E2F site occupation in vivo. Science (80-) 1996;271(5255):1595-7.

51. Pandit KV, Milosevic J, Kaminski N. MicroRNAs in idiopathic pulmonary fibrosis. Transl Res 2011;157(4):191-9.

52. Roderburg C, Urban G-W, Bettermann K, Vucur M, Zimmermann H, Schmidt S, Janssen J, Koppe C, Knolle P, Castoldi M, Tacke F Trautwein C, Luedde T. Micro-RNA profiling reveals a role for miR-29 in human and murine liver fibrosis. Hepatology 2011;53(1):209-18.

53. Pandit KV, Corcoran D, Yousef $H$, Yarlagadda M, Tzouvelekis A, Gibson KF, Konishi K, Yousem SA, Singh M, Handley D, Richards T, Selman M, Watkins SC, Pardo A, Ben-Yehudah A, Bouros D, Eickelberg O, Ray P, Benos P V, Kaminski N. Inhibition and role of let-7d in idiopathic pulmonary fibrosis. Am J Respir Crit Care Med 2010;182(2):220--9.

54. Maurer B, Stanczyk J, Jüngel A, Akhmetshina A, Trenkmann M, Brock M, Kowal-Bielecka O, Gay RE, Michel BA, Distler JH, Gay S, Distler O. MicroRNA-29, a key regulator of collagen expression in systemic sclerosis. Arthritis Rheum 2010;62(6):1733-43.

55. Pekarsky Y, Croce CM. Is miR-29 an oncogene or tumor suppressor in CLL? Oncotarget 2010;1(3):224-7.

56. Garzon R, Volinia S, Liu C-G, Fernandez-Cymering C, Palumbo T, Pichiorri F, Fabbri M, Coombes K, Alder H, Nakamura T, Flomenberg N, Marcucci G, Calin GA, Kornblau SM, Kantarjian H, Bloomfield $\mathrm{CD}$, Andreeff M, Croce CM. MicroRNA signatures associated with cytogenetics and prognosis in acute myeloid leukemia. Blood 2008;111(6):3183-9.

57. Calin GA, Ferracin M, Cimmino A, Di Leva G, Shimizu M, Wojcik SE, lorio M V, Visone R, Sever NI, Fabbri M, luliano R, Palumbo T, Pichiorri F, Roldo C, Garzon R, Sevignani C, Rassenti L, Alder H, Volinia S, Liu C, Kipps TJ, Negrini M, Croce CM. A MicroRNA signature associated with prognosis and progression in chronic lymphocytic leukemia. N Engl J Med 2005;353(17):1793-801.

58. Teichler S, Illmer T, Roemhild J, Ovcharenko D, Stiewe T, Neubauer A. MicroRNA29a regulates the expression of the nuclear oncogene Ski. Blood 2011;118(7):1899-902.

59. Garzon R, Garofalo M, Martelli MP, Briesewitz R, Wang L, FernandezCymering C, Volinia S, Liu C-G, Schnittger S, Haferlach T, Liso A Diverio D, Mancini M, Meloni G, Foa R, Martelli MF, Mecucci C, Croce CM, Falini B. Distinctive microRNA signature of acute myeloid leukemia bearing cytoplasmic mutated nucleophosmin. Proc Natl Acad Sci U S A 2008;105(10):3945-50.

60. Wang F, Wang X-S, Yang G-H, Zhai P-F, Xiao Z, Xia L-Y, Chen L-R, Wang Y, Wang X-Z, Bi L-X, Liu N, Yu Y, Gao D, Huang B-T, Wang J, Zhou D-B, Gong J-N, Zhao H-L, Bi X-H, Yu J, Zhang J-W. miR-29a and miR-142-3p downregulation and diagnostic implication in human acute myeloid leukemia. Mol Biol Rep 2012;39(3):2713-22.

61. Calin GA, Liu C-G, Sevignani C, Ferracin M, Felli N, Dumitru CD, Shimizu M, Cimmino A, Zupo S, Dono M, Dell'Aquila ML, Alder $\mathrm{H}_{\text {, }}$ Rassenti L, Kipps TJ, Bullrich F, Negrini M, Croce CM. MicroRNA profiling reveals distinct signatures in $B$ cell chronic lymphocytic leukemias. Proc Natl Acad Sci U S A 2004;101(32):11755-60.

62. Zanette DL, Rivadavia F, Molfetta GA, Barbuzano FG, Proto-Siqueira R, Falcão RP, Zago MA, Silva-Jr WA. miRNA expression profiles in chronic lymphocytic and acute lymphocytic leukemia. Braz J Med Biol Res 2007;40(11):1435-40.

63. Zhu C, Wang Y, Kuai W, Sun X, Chen H, Hong Z. Prognostic value of miR-29a expression in pediatric acute myeloid leukemia. Clin Biochem 2013;46(1-2):49-53.

64. Zhou P, Levy NP, Xie H, Qian L, Lee C-YG, Gascoyne RD, Craig RW. MCL1 transgenic mice exhibit a high incidence of B-cell lymphoma manifested as a spectrum of histologic subtypes. Blood 2001;97(12):3902-9.

65. Pekarsky Y, Koval A, Hallas C, Bichi R, Tresini M, Malstrom S, Russo G, Tsichlis P, Croce CM. Tcl1 enhances Akt kinase activity and mediates its nuclear translocation. Proc Natl Acad Sci U S A 2000;97(7):302833.

66. Laine J, Künstle G, Obata T, Sha M, Noguchi M. The protooncogene TCL1 is an Akt kinase coactivator. Mol Cell 2000;6(2):395-407.

67. Amodio N, Di Martino MT, Foresta U, Leone E, Lionetti M, Leotta M, Gullà AM, Pitari MR, Conforti F, Rossi M, Agosti V, Fulciniti M, Misso G, Morabito F, Ferrarini M, Neri A, Caraglia M, Munshi NC, Anderson KC, Tagliaferri P, Tassone P. miR-29b sensitizes multiple myeloma cells to bortezomib-induced apoptosis through the activation of a feedback loop with the transcription factor Sp1. Cell Death Dis [serial on the Internet]. 2012 Jan [cited 2013 Mar 6]; 3:[about 11 p.]. Available from: http://www.nature.com/cddis/journal/v3/n11/full/ cddis2012175a.html.

68. Fulciniti M, Amin S, Nanjappa P, Rodig S, Prabhala R, Li C, Minvielle S, Tai Y-T, Tassone P, Avet-Loiseau H, Hideshima T, Anderson KC, Munshi NC. Significant biological role of Sp1 transactivation in multiple myeloma. Clin Cancer Res 2011;17(20):6500-9.

69. Rossi M, Pitari MR, Amodio N, Di Martino MT, Conforti F, Leone E, Botta C, Paolino FM, Del Giudice T, luliano E, Caraglia M, Ferrarini M, Giordano A, Tagliaferri P, Tassone P. miR-29b negatively regulates human osteoclastic cell differentiation and function: Implications for the treatment of multiple myeloma-related bone disease. J Cell Physiol 2013;228(7):1506-15.

70. Chen X, Ba Y, Ma L, Cai X, Yin Y, Wang K, Guo J, Zhang Y, Chen J, Guo X, Li Q, Li X, Wang W, Zhang Y, Wang J, Jiang X, Xiang Y, Xu C, Zheng P, Zhang J, Li R, Zhang H, Shang X, Gong T, Ning G, Wang J, Zen $\mathrm{K}$, Zhang J, Zhang C-Y. Characterization of microRNAs in serum: a novel class of biomarkers for diagnosis of cancer and other diseases. Cell Res [serial on the Internet]. 2008 Oct [cited 2013 Nov 7]; 18(10):[about 997-1006 p.]. Available from: http://www.ncbi.nlm. nih.gov/pubmed/18766170.

71. Lawrie $\mathrm{CH}$, Gal S, Dunlop HM, Pushkaran B, Liggins AP, Pulford K, Banham AH, Pezzella F, Boultwood J, Wainscoat JS, Hatton CSR, Harris AL. Detection of elevated levels of tumour-associated microRNAs in serum of patients with diffuse large B-cell lymphoma. Br J Haematol 2008;141(5):672-5.

72. Mitchell PS, Parkin RK, Kroh EM, Fritz BR, Wyman SK, PogosovaAgadjanyan EL, Peterson A, Noteboom J, O'Briant KC, Allen A, Lin DW, Urban N, Drescher CW, Knudsen BS, Stirewalt DL, Gentleman R, Vessella RL, Nelson PS, Martin DB, Tewari M. Circulating microRNAs as stable blood-based markers for cancer detection. Proc Natl Acad Sci U S A 2008;105(30):10513-8.

73. Weber JA, Baxter DH, Zhang S, Huang DY, Huang KH, Lee MJ, Galas DJ, Wang K. The microRNA spectrum in 12 body fluids. Clin Chem 2010;56(11):1733-41.

74. Arroyo JD, Chevillet JR, Kroh EM, Ruf IK, Pritchard CC, Gibson DF, Mitchell PS, Bennett CF, Pogosova-Agadjanyan EL, Stirewalt DL, Tait JF, Tewari M. Argonaute2 complexes carry a population of circulating microRNAs independent of vesicles in human plasma. Proc Natl Acad Sci U S A 2011;108(12):5003-8.

75. Wang K, Zhang S, Weber J, Baxter D, Galas DJ. Export of microRNAs and microRNA-protective protein by mammalian cells. Nucleic Acids Res 2010;38(20):7248-59.

76. Vickers KC, Palmisano BT, Shoucri BM, Shamburek RD, Remaley AT. MicroRNAs are transported in plasma and delivered to recipient cells by high-density lipoproteins. Nat Cell Biol 2011;13(4):423-33.

77. Kosaka N, Iguchi H, Yoshioka Y, Takeshita F, Matsuki Y, Ochiya T. Secretory mechanisms and intercellular transfer of microRNAs in living cells. J Biol Chem 2010;285(23):17442-52.

78. Camussi G, Deregibus M-C, Bruno S, Grange C, Fonsato V, Tetta C Exosome/microvesicle-mediated epigenetic reprogramming of cells. Am J Cancer Res 2011;1(1):98-110.

79. Mittelbrunn M, Gutiérrez-Vázquez C, Villarroya-Beltri C, González S, Sánchez-Cabo F, González MÁ, Bernad A, Sánchez-Madrid F. 
Unidirectional transfer of microRNA-loaded exosomes from T cells to antigen-presenting cells. Nat Commun [serial on the Internet]. 2011 Jan [cited 2013 Sep 20]; 2:[about 10 p.]. Available from: http:// www.nature.com/ncomms/journal/v2/n4/full/ncomms1285.html.

80. Katakowski M, Buller B, Wang X, Rogers T, Chopp M. Functional microRNA is transfered betweeb glioma cells. Cancer Res 2010;70(21):8259-63.

81. Pigati L, Yaddanapudi SC, Iyengar R, Kim D-J, Hearn S a, Danforth $D$, Hastings ML, Duelli DM. Selective release of microRNA species from normal and malignant mammary epithelial cells. PLoS One [serial on the Internet]. 2010 Jan [cited 2013 Nov 10]; 5(10):[about 13 p.]. Available from: http://www.plosone.org/article/ info\%3Adoi\%2F10.1371\%2Fjournal.pone.0013515.

82. Sevcikova S, Kubiczkova L, Sedlarikova L, Slaby O, Hajek R. Serum miR-29a as a marker of multiple myeloma. Leuk Lymphoma 2013;54(1):189-91.

83. Moussay E, Wang K, Cho J-H, van Moer K, Pierson S, Paggetti J, Nazarov P V, Palissot V, Hood LE, Berchem G, Galas DJ. MicroRNA as biomarkers and regulators in B-cell chronic lymphocytic leukemia. Proc Natl Acad Sci U S A 2011;108(16):6573-8.

84. Zenz T, Mertens D, Küppers R, Döhner H, Stilgenbauer S. From pathogenesis to treatment of chronic lymphocytic leukaemia. Nat Rev Cancer 2010;10(1):37-50. 